OPEN ACCESS

Edited by:

Ali A. Zarrin,

TRex Bio, United States

Reviewed by:

Marc Seifert,

Essen University Hospital, Germany

Lars Nitschke,

University of Erlangen Nuremberg,

Germany

Andre Veillette,

Institute of Clinical Research De

Montreal (IRCM), Canada

*Correspondence:

Timo K. van den Berg

t.k.vandenberg@sanquin.nl

Specialty section:

This article was submitted to

Molecular Innate Immunity,

a section of the journal

Frontiers in Immunology

Received: 09 June 2020 Accepted: 17 September 2020

Published: 09 October 2020

Citation:

Franke K, Pillai SY, Hoogenboezem M, Giijbels MJJ, Matlung HL, Geissler J, Olsman H, Pottgens C, van Gorp PJ, Ozsvar-Kozma M, Saito Y, Matozaki T,

Kuijpers TW, Hendriks RW, Kraal G,

Binder CJ, de Winther MPJ and van den Berg TK (2020) SIRP $\alpha$ on Mouse B1 Cells Restricts Lymphoid

Tissue Migration and Natural Antibody Production.

Front. Immunol. 11:570963. doi: 10.3389/fimmu.2020.570963

\section{SIRP $\alpha$ on Mouse B1 Cells Restricts Lymphoid Tissue Migration and Natural Antibody Production}

Katka Franke ${ }^{1}$, Saravanan Y. Pillai ${ }^{2}$, Mark Hoogenboezem ${ }^{3}$, Marion J. J. Gijbels ${ }^{4,5}$, Hanke L. Matlung ${ }^{1}$, Judy Geissler ${ }^{1}$, Hugo Olsman ${ }^{1}$, Chantal Pottgens ${ }^{4}$, Patrick J. van Gorp ${ }^{4}$, Maria Ozsvar-Kozma ${ }^{6}$, Yasuyuki Saito ${ }^{7}$, Takashi Matozaki ${ }^{7}$, Taco W. Kuijpers ${ }^{1,8}$, Rudi W. Hendriks ${ }^{2}$, Georg Kraal ${ }^{9}$, Christoph J. Binder ${ }^{6}$, Menno P. J. de Winther ${ }^{4,10}$ and Timo K. van den Berg ${ }^{1,9 *}$

\footnotetext{
1 Sanquin Research and Landsteiner Laboratory, Department of Blood Cell Research, Amsterdam UMC, University of Amsterdam, Amsterdam, Netherlands, ${ }^{2}$ Department of Pulmonary Medicine, Erasmus MC, Rotterdam, Netherlands, ${ }^{3}$ Sanquin Research and Landsteiner Laboratory, Department of Plasma Protein, Amsterdam UMC, University of Amsterdam, Amsterdam, Netherlands, ${ }^{4}$ Department of Medical Biochemistry, Experimental Vascular Biology, Amsterdam UMC, University of Amsterdam, Amsterdam, Netherlands, ${ }^{5}$ Department of Pathology, CARIM, Cardiovascular Research Institute Maastricht, GROW-School for Oncology and Developmental Biology, Maastricht University, Maastricht, Netherlands, ${ }^{6}$ Department of Laboratory Diagnostics, Medical University of Vienna, Vienna, Austria, ${ }^{7}$ Division of Molecular and Cellular Signaling, Department of Biochemistry and Molecular Biology, Kobe University Graduate School of Medicine, Kobe, Japan, ${ }^{8}$ Department of Pediatric Hematology, Immunology and Infectious Disease, Emma Children's Hospital, Academic Medical Center, University of Amsterdam, Amsterdam, Netherlands, ${ }^{9}$ Department of Molecular Cell Biology and Immunology, Amsterdam UMC, Vrije Universiteit Amsterdam, Amsterdam Infection and Immunity Institute, Amsterdam, Netherlands, 10 Institute for Cardiovascular Prevention (IPEK), Munich, Germany
}

The inhibitory immunoreceptor SIRP $\alpha$ is expressed on myeloid and neuronal cells and interacts with the broadly expressed CD47. CD47-SIRP $\alpha$ interactions form an innate immune checkpoint and its targeting has shown promising results in cancer patients. Here, we report expression of SIRP $\alpha$ on B1 lymphocytes, a subpopulation of murine B cells responsible for the production of natural antibodies. Mice defective in $\operatorname{SIRP} \alpha$ signaling (SIRP $\alpha^{\Delta C Y T}$ mice) displayed an enhanced CD11b/CD18 integrin-dependent B1 cell migration from the peritoneal cavity to the spleen, local B1 cell accumulation, and enhanced circulating natural antibody levels, which was further amplified upon immunization with T-independent type 2 antigen. As natural antibodies are atheroprotective, we investigated the involvement of $\operatorname{SIRP} \alpha$ signaling in atherosclerosis development. Bone marrow (SIRP $\alpha^{\Delta \mathrm{CYT}}>\mathrm{LDLR}^{-/-}$) chimaeric mice developed reduced atherosclerosis accompanied by increased natural antibody production. Collectively, our data identify $\operatorname{SIRP} \alpha$ as a unique B1 cell inhibitory receptor acting to control B1 cell migration, and imply $\mathrm{SIRP} \alpha$ as a potential therapeutic target in atherosclerosis.

Keywords: B1 cells, natural antibodies, atherosclerosis, immune checkpoint, inhibitory receptor, SIRP $\alpha$, CD47, CD11b/CD18-integrin 


\section{INTRODUCTION}

Signal regulatory protein alpha (SIRP $\alpha$ ) is an inhibitory immunoreceptor known to be expressed on myeloid and neuronal cells. SIRP $\alpha$ interacts with the broadly expressed cell surface ligand CD47 present on most cells in the body, including both hematopoietic and non-hematopoietic cells (1). Binding of CD47 to SIRP $\alpha$ generates intracellular inhibitory signals via immunoreceptor tyrosine-based inhibitory motifs (ITIM) in the cytoplasmic tail of SIRP $\alpha$. Upon phosphorylation the SIRP $\alpha$ ITIM act to recruit and activate the tyrosine phosphatases SHP-1 and/or SHP-2, which inhibit tyrosine-phosphorylation-dependent signaling events and the resultant downstream cellular effector functions, including, e.g., phagocytosis (1). As such, the CD47SIRP $\alpha$ axis forms an important innate immune checkpoint, with CD47 acting as so-called "don't-eat-me" signal, which prevents the engulfment of healthy cells by myeloid cells (2). However, aberrant cells, such as cancer cells, may also exploit this pathway by (over) expressing CD47 and thus escaping immune-mediated destruction. Therapeutic targeting of the CD47-SIRP $\alpha$ checkpoint has been most intensively explored in the context of cancer. In fact, recent first in-human studies of agents interfering with this pathway demonstrate a favorable safety profile and promising therapeutic potential (3).

Based on their functions, anatomical location and phenotypical properties B lymphocytes can be divided into conventional B cells, also known as B2 cells, representing the majority of B cells, and into a smaller population of unconventional B1 cells. In mice, B1 cells are produced in the fetal liver before birth and afterward reside mainly in the pleural and peritoneal cavities where they are maintained by self-renewal (4). In addition, small proportions $(<1 \%)$, but significant numbers, of these cells can be found in spleen and bone marrow (4-6). B1 cells residing in body cavities have a limited capacity to produce natural antibodies. However, after stimulation, by, e.g., LPS or viral infection, they migrate to the secondary lymphoid tissues, including the spleen, where they differentiate into plasma cells forming the major systemic source of natural antibodies $(7,8)$. This conditional migration is governed by the CD11b/CD18 integrin $(7,9)$. B1 cells that have arrived to the spleen gradually lose expression of $\mathrm{CD} 11 \mathrm{~b} / \mathrm{CD} 18$ integrin, with hardly detectable levels after 6 days (9). Peritoneal B1 cells represent about $35 \%-70 \%$ of all $\mathrm{CD} 19^{+}$cells present in the peritoneal cavity and can

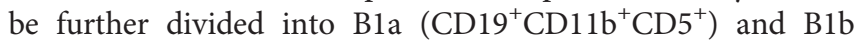
$\left(\mathrm{CD} 19^{+} \mathrm{CD} 11 \mathrm{~b}^{+} \mathrm{CD}^{-}\right)$cells (4). Unlike B2 cells, B1 cells in the spleen constitutively secrete natural antibodies, which are IgM antibodies commonly targeting, e.g., phospholipid and polysaccharide antigens, such as phosphorylcholine, phosphatidylcholine and lipopolysaccharide (4). Notably, a large part of the natural IgM antibodies is directed against epitopes created through lipid peroxidation (so called oxidation-specific epitopes, OSE), expressed amongst others on apoptotic cells and modified lipoproteins (10). Protective effects of natural antibodies against oxidized lipids have been well established in atherosclerosis (11-14), a chronic inflammatory disease characterized by accumulation of modified (oxidized) lipids in big and medium sized arteries (15). The atheroprotective capacity of IgM antibodies is explained by their binding to oxLDL, thereby preventing oxLDL uptake by macrophages, which as a consequence reduces foam cell formation and lesion development $(11,16)$. Additionally, natural antibodies are produced to promote clearance of apoptotic cells, which carry the same OSE as oxLDL (14).

It is known that B1 cell responses are restricted by different inhibitory immunoreceptors expressed on these cells, including, e.g., CD5 (17), CD22 (18), Fc gamma receptor IIb (FcyRIIb) (19, $20)$, and Siglec-G $(21,22)$. CD5 has been strongly linked to inhibition of BCR signaling, which prevents unwanted selfreactivity of B1 cells (23). B1 cells from mice lacking Siglec-G show a dramatic increase in $\mathrm{Ca}^{2+}$ flux upon anti-IgM treatment (22) and increased natural antibody production (24), also suggesting a role of Siglec-G in BCR signaling. All these receptors commonly exhibit their inhibitory functions through intracellular immunoreceptor tyrosine-based inhibitory motifs (ITIM), which upon tyrosine phosphorylation recruit and activate the cytosolic tyrosine phosphatases SHP-1 and/or SHP-2. In the case of FcyRIIb, the inositol phosphatases SHIP1 and/or SHIP-2 play a prominent role as mediators of inhibitory signaling (25).

Here, we describe another inhibitory receptor, SIRP $\alpha$, which is expressed on B1 cells in mice. We demonstrate that, in contrast to other currently known inhibitory receptors, SIRP $\alpha$ on B1 cells negatively regulates their migration, B1 cell numbers in the spleen, and systemic natural antibody production, without directly affecting B1 cell activation. Mice lacking the cytoplasmic tail of SIRP $\alpha\left(\right.$ SIRP $\alpha^{\Delta C Y T}$ mice) in their hematopoietic compartment are protected against atherosclerosis with increased natural antibody levels against oxidized lipids. This identifies SIRP $\alpha$ as a novel immunoinhibitory receptor on B1 cells with unique regulatory functions and potential for therapeutic targeting in atherosclerosis.

\section{MATERIALS AND METHODS}

\section{Mice}

SIRP $\alpha^{-/-}$mice maintained on a C57BL/6 background have been described and were maintained in the Institute for Experimental Animals at Kobe University Graduate School of Medicine under specific-pathogen free conditions (26). C57BL/6 mice with a targeted deletion of the SIRP $\alpha$ cytoplasmic region have been described previously $(27,28)$. The mice that were originally generated onto the 129/Sv background were backcrossed onto C57BL/6 mice for at least 13 generations. Wild-type (wt) C57BL/ 6 mice of the same genetic background were maintained under specific pathogen-free conditions together with the SIRP $\alpha^{\Delta C Y T}$ mice in the breeding facility of The Netherlands Cancer Institute, Amsterdam, The Netherlands or the VU Medical Center, Amsterdam, The Netherlands. Unless indicated otherwise littermates from heterozygous breedings were used for both wild type and mutant mice. Bone marrow was isolated and used for transplantation at the animal facility of Maastricht University, Maastricht, The Netherlands. Animals were housed in ventilated cages and treated according to European Commission guidelines. They were euthanized using combination of isofluran and $\mathrm{CO}_{2}$. All animal experiments were approved by the Animal Welfare Committee of the VU Medical Center Amsterdam, The 
Netherlands, Maastricht University, Maastricht, The Netherlands, and The Netherlands Cancer Institute, Amsterdam, The Netherlands. LDLR $^{-1-}$ mice on C57BL/6J background were obtained from Jackson Laboratory (Bar Harbor, ME, USA).

\section{Flow Cytometric Analysis of SIRP $\alpha$ Expression on Mouse B Cells}

Mouse B cells were isolated from the peritoneal cavity by peritoneal lavage of $8-12$ weeks old SIRP $\alpha^{\Delta \mathrm{CYT}}$ mice and age matched wt mice. Mice were sacrificed and immediately after that $5 \mathrm{ml}$ of cold PBS containing 3\% of fetal calf serum (FCS) and $3 \mathrm{mM}$ EDTA was injected into their peritoneal cavity. After gentle massage, cells were collected and used for analysis of SIRP $\alpha$ expression. Additionally, bone marrow and spleens of the same mice were isolated and blood samples were taken to analyze for expression of SIRP $\alpha$. Fetal livers were isolated from mice of FVB background at E12. Single cell suspensions of splenocytes were prepared after the spleens were homogenized through $100 \mu \mathrm{m}$ filter (BD Biosciences, Bedford, MA, USA), lysed with lysis buffer and washed twice with cold PBS. For blood analysis whole blood was first spun down at 2,000 rpm at $4^{\circ} \mathrm{C}$ for $10 \mathrm{~min}$ and plasma was collected and stored at $-80^{\circ} \mathrm{C}$ for later analysis of antibodies level. Erythrocytes were lysed using cold lysis buffer containing $155 \mathrm{mM} \mathrm{NH}_{4} \mathrm{Cl}, 10 \mathrm{mM} \mathrm{KHCO} 3$, and $0.1 \mathrm{mM}$ EDTA (ethylene diamine tetra acetic acid), $\mathrm{pH}$ 7.4. For flow cytometry analysis first Fc receptors were blocked using $\alpha$-CD16/CD32 antibody (clone 2.4G2, BD Biosciences, Bedford, MA, USA). The cells were subsequently washed and stained for following surface markers with directly conjugated antibodies against CD19/B220 (PerCP Cy5.5 or eFluor 450), CD11b (Alexa Fluor 488), CD5 (PE), IgM (PE), SIRP $\alpha$ (APC or PerCP 710) (all antibodies purchased from eBioscience, San Diego, CA, USA), and CD43 (APC Cy7, BioLegend, San Diego, CA, USA). Expression of proteins was measured using FACS Canto II HTS (BD Biosciences, Bedford, MA, USA) and analyzed using FlowJo software (FlowJo LLC, Ashland, OR, USA). To reliably detect SIRP $\alpha$ expression and separate it from autofluorescence, fluorescence minus one (FMO) control was applied, when cells were stained for all determinants except SIRP $\alpha$ (9).

\section{Quantitative RT-PCR to Determine SIRP $\alpha$ mRNA Expression}

RNA was isolated from FACS sorted mouse B1a and B2 cells based on markers listed above with QIAamp RNA Blood mini kit according to manufacturer's instructions (Qiagen, Venlo, The Netherlands). RNA was eluted with $30 \mu \mathrm{H} 2 \mathrm{O}$, to obtain as high as possible concentration of RNA. Total RNA was reverse transcribed using the III first-strand synthesis system for RT-PCR (Invitrogen, Breda, The Netherlands). In short, 8- $\mu$ RNA was primed with $2.5 \mu \mathrm{M}$ oligo-dT primer which specifically targets mRNA and $0.5 \mathrm{mM} \mathrm{dNTP} \mathrm{for} 5 \mathrm{~min}$ at $65^{\circ} \mathrm{C}$. Reverse transcription was performed with $10 \mathrm{U} / \mu \mathrm{l}$ Superscript III in the presence of $5 \mathrm{mM}$ $\mathrm{MgCl}_{2}, 20 \mathrm{mM}$ Tris-HCL, and $50 \mathrm{mM} \mathrm{KCl}, \mathrm{pH} 8.4$ (RT buffer), $2 \mathrm{U} /$ $\mu \mathrm{RNAseOUT}{ }^{\mathrm{TM}}$, lacking DTT for reasons described before (29) for $50 \mathrm{~min}$ at $50^{\circ} \mathrm{C}$. After that, Superscript III was inactivated by incubation for $5 \mathrm{~min}$ at $85^{\circ} \mathrm{C}$, followed by chilling on ice.
Immediately thereafter, $2 \mathrm{U}$ RNase $\mathrm{H}$ was added and incubated at $37^{\circ} \mathrm{C}$ for $20 \mathrm{~min}$. Subsequently $\mathrm{cDNA}$ was stored at $-20^{\circ} \mathrm{C}$ until further use. Amplification by PCR was performed on a LightCycler instrument (Roche, Almere, The Netherlands), with software version 3.5. The reaction was performed with Lightcycler FastStart DNA Master ${ }^{\text {PLUS }}$ SYBR Green I (Roche, Almere, The Netherlands). The annealing temperature used for all primers was $60^{\circ} \mathrm{C}$. The reaction mix consisted of $4 \mu \mathrm{l}$ of cDNA, $1 \mu \mathrm{M}$ of each primer combination and $4 \mu \mathrm{l}$ of Lightcycler FastStart DNA

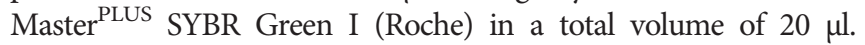
After an incubation step for $10 \mathrm{~min}$ at $95^{\circ} \mathrm{C}$, the template was amplified for 45 cycles at $95^{\circ} \mathrm{C}$, annealing of the primers was performed at $60^{\circ} \mathrm{C}$ for $30 \mathrm{~s}$, followed by extension at $72^{\circ} \mathrm{C}$ for 15 s. At the end of the 45 cycles, a melting curve was generated to determine the unique features of the DNA amplified. cDNA of control wt animals was used as a standard curve with a serial 10-fold dilution. Musculus Ubiquitin $\mathrm{C}$ was used as a reference gene. The product was sequenced by Big-dye Terminator Sequencing and ABI Prism software (Applied Biosystems, Foster City, USA). The sequence obtained was verified with BLAST (http://www.ncbi. nlm.nih.gov/BLAST/) to determine specificity. Primer sequences are available upon request.

\section{Binding of Phosphatidylcholine by Primary Mouse B Cells}

$\mathrm{B}$ cells were isolated and labeled with antibodies against surface CD5 and B220 as described above along with fluorescein-labeled phosphatidylcholine (PtC) liposomes (DOPC/CHOL 55:45, Formumax Scientific Inc.). The cells were incubated on ice for $20 \mathrm{~min}$ followed by two washing steps, then cells were analyzed using an LSRII flow cytometer (BD Biosciences, Bedford, MA, USA) for binding of phosphatidylcholine and data were processed with FlowJo software (FlowJo LLC, Ashland, OR, USA).

\section{Intracellular Calcium Mobilization Measurement in Primary Mouse B1a Cells}

$B$ cells were isolated from the peritoneal cavity of 8-12 weeks old SIRP $\alpha^{\Delta C Y T}$ mice and aged matched wt mice using peritoneal lavage as described above. First, Fc receptors were blocked using $\alpha$-CD16/CD32 antibody (clone 2.4G2, BD Biosciences, Bedford, MA, USA). The cells were then stained with directly labeled antibody against CD5 (APC) and B220 (APC Cy7, both BD Biosciences, Bedford, MA, USA) allowing identification of B1a cells. Calcium flux was determined as described before by flow cytometric determination (30). Briefly, intracellular fluxes of $\mathrm{Ca}^{2+}$ were measured using Fluo-3-AM and Fura Red-AM fluorogenic probes (Life Technologies, Carlsbad, CA, USA). The cells were incubated with $5 \mu$ Fluo3-AM and $5 \mu \mathrm{M}$ Fura Red-AM in loading buffer (Hank's balanced salt solution medium supplemented with $10 \mathrm{mM}$ HEPES and 5\% fetal calf serum) at $30^{\circ} \mathrm{C}$ for $30 \mathrm{~min}$ in the dark. Cells were then washed and resuspended in buffer (Hank's balanced salt solution medium with $10 \mathrm{mM}$ HEPES, 5\% fetal calf serum and $1 \mathrm{mM}$ $\mathrm{CaCl} 2$ ) at room temperature. Cells were warmed to $37^{\circ} \mathrm{C}$ for 5 min before acquisition of events. BCR-mediated $\mathrm{Ca}^{+}$ mobilization was measured for $60 \mathrm{~s}$ after the cells were 
stimulated either with $10 \mu \mathrm{g} / \mathrm{ml} \mathrm{F}\left(\mathrm{ab}^{\prime}\right) 2$ of polyclonal goat antimouse IgM (Jackson ImmunoResearch, West Grove, PA, USA) or $0.5 \mathrm{mM}$ phosphatidylcholine (PtC) (F60103F-F, FormuMax USA). At the end of each $\mathrm{Ca}^{2+}$ measurement, cells were treated with ionomycine (Life Technologies, Eugene, OR, USA) as a positive control for calcium signaling. Data were acquired on an LSRII flow cytometer (BD Biosciences, Bedford, MA, USA) and data analysis was performed with the use of FlowJo software (FlowJo LLC, Ashland, OR, USA).

\section{Immunization of Mice With DNP-Ficoll}

For B1-specific immunization intraperitoneal injection of TI-2 antigen di-nitro phenyl (DNP)-Ficoll was used as described originally in (31). Briefly, mice were injected with $50 \mu \mathrm{g}$ of DNP-Ficoll in 200- $\mu$ l PBS solution or with $200 \mu$ lof PBS only as control. After 7 days animals were sacrificed and their blood was collected, plasma was harvested and stored at $-80^{\circ} \mathrm{C}$ before analysis of IgM and IgG3 antibodies by ELISA.

\section{Measurement of IgM and IgG With ELISA}

Plasma levels of IgM antibodies against several OSE were determined by chemiluminescent ELISA (32). Dilutions of 1:100 [anti-phosphocholine (PC)-BSA IgM and all IgG antibodies], 1:500 [E06/T15id+ IgM, anti-malondialdehyde (MDA-)LDL IgM, anti$\mathrm{Cu}-\mathrm{OxLDL}$ IgM], and 1:20.000 (total IgM) were used. Supernatants of peritoneal $\mathrm{B} 1$ cell cultures or plasma of mice were serially diluted to determine IgM production after $48 \mathrm{~h}$ of stimulation or IgM/IgG3 against DNP-Ficoll after 7-days immunization as previously described (33). Briefly, supernatants were measured by sandwich ELISA, using unlabeled for coating and peroxidase-labeled antimouse IgM/IgG antibody (total, or DNP-Ficoll specific, Southern Biotechnology, Birmingham, AL, USA) for detection, and azino-bisethylbenz-thiazoline sulfonic acid was used as the substrate. Antibody concentrations were calculated by using purified mouse IgM protein (IgM DNP-Ficoll and IgG3 DNP-Ficoll PMP52, Serotec, UK) as a standard.

\section{Proliferation of B1 Cells}

$B$ cells were isolated from the peritoneal cavity of either wt or SIRP $\alpha^{\Delta C Y T}$ mice and either left unstimulated or incubated with various stimuli for $48 \mathrm{~h}$ after labeling with CFSE dye. Dilution of the dye after cell division was determined by flow cytometry on B1a cells (gated for CD19+, CD5+, CD11b+ lymphocytes) and percentage of proliferating cells was calculated.

\section{Stimulation of Peritoneal B1 Cell}

Peritoneal B1a cells were obtained through negative magneticactivated cell separation with a cocktail of antibodies depleting other than B1a cells achieving more than $90 \%$ purity in isolation (Miltenyi Biotec B.V., Utrecht, The Netherlands). B1a cells were subsequently counted and plated in IMDM medium (Invitrogen, Eugene, OR, USA) supplemented with 10\% fetal calf-serum (FCS; Bodinco, Alkmaar, The Netherlands, $100 \mathrm{U} / \mathrm{ml}$ of penicillin, $100 \mathrm{mg} / \mathrm{ml}$ of streptomycin, and $2 \mathrm{mM} \mathrm{L}$-glutamine (all Gibco Invitrogen, Breda, The Netherlands), and betamercapthoethanol $\left(3.57 \times 10^{-4} \mathrm{M}\right.$; Millipore, Amsterdam, The Netherlands). Cells were plated in 96-well plate in density of $1 \times$
$10^{6} / \mathrm{ml}$ in $200 \mu \mathrm{l}$ of medium and cultured at $37^{\circ} \mathrm{C}$ and $5 \% \mathrm{CO} 2$ for $48 \mathrm{~h}$ in presence of $5 \mu \mathrm{g}$ of lipopolysaccharide (LPS, isolated from E. coli strain 055:B5, Sigma, St. Louis, MO, USA; LBP from $\mathrm{R} \& \mathrm{D}$ Systems, Abingdon, UK), isotype control (rat IgG2b, eBioscience, San Diego, CA, USA), anti-CD11b antibody (functional grade, eBioscience, San Diego, CA, USA), or antiCD11a (functional grade, eBioscience, San Diego, CA, USA) in final concentration $10 \mu \mathrm{g} / \mathrm{ml}$. After that supernatant was collected and stored at $-80^{\circ} \mathrm{C}$ before measurement of IgM antibody by ELISA. Cells were harvested and processed for analysis by flow cytometry and imaging cytometry.

\section{Image Stream Analysis of Aggregate Formation}

LPS-stimulated B1a cells were stained with following antibodies: CD19 (PerCP Cy5.5), CD11b (Alexa Fluor 488), CD5 (PE), SIRP $\alpha$ (APC), (all antibodies purchased from eBioscience, San Diego, CA, USA) and analyzed imaging cytometry to detect formation of aggregates (Image Stream, (Image Stream, Amnis, EMD, Millipore, Seattle, WA, USA) with gating strategy as follows: all events were divided based on their size into single cells ( 1 cell); doublets ( 2 cells); doublets and small aggregates (23 cells); big aggregates (3-4 cells); and large aggregates ( $>4$ cells). Analysis of data was performed using analysis software IDEAS (Amnis Corporation, Seattle, WA, USA) and depicted as percentage of all gated events.

\section{Adoptive Transfer of Peritoneal B1 Cells}

Either wt or SIRP $\alpha^{\Delta \mathrm{CYT}}$ animals were used as donors of peritoneal B1 cells for adoptive transfer. Cells were harvested by peritoneal lavage as described above. The cells were left in IMDM medium supplemented with $10 \%$ FCS (Bodinco, Alkmaar, The Netherlands, $100 \mathrm{U} / \mathrm{ml}$ of penicillin, $100 \mathrm{mg} / \mathrm{ml}$ of streptomycin, and $2 \mathrm{mM}$ L-glutamine (all Gibco Invitrogen, Breda, The Netherlands) to rest for $30 \mathrm{~min}$. After that the easy to detach and floating cells (excluding adherent peritoneal macrophages) were first incubated with Fc receptor blocking antibody (antiCD16/CD32) and after washing incubated with either isotype control (rat IgG2b, eBioscience, San Diego, CA, USA) or antiCD11b antibody (functional grade, eBioscience, San Diego, CA, USA) in concentration of $10 \mu \mathrm{g} / \mathrm{ml}$ for $30 \mathrm{~min}$. Antibodies were washed away and wt and SIRP $\alpha^{\Delta C Y T}$ cells were labeled with membrane dye $\mathrm{DiD}$ and $\mathrm{DiO}$, respectively (or vice versa, to exclude effect of the dye on cell properties). Cells were washed multiple times and mixed in 50:50 ratio based on a cell count. The actual ratio was additionally determined by analyzing a small sample of pooled cells on flow cytometer allowing later normalization of the cell input. Cells were then injected into the peritoneal cavity of either wt or SIRP $\alpha^{\Delta C Y T}$ recipient mice, left resting for $1 \mathrm{~h}$, and followed by either 200- $\mu$ linjection of PBS (control) or $10 \mu \mathrm{g}$ of LPS in 200- $\mu$ l PBS intraperitoneally to induce migration of $\mathrm{B} 1$ cells from the peritoneal cavity $(7,33)$. Peritoneal lavage of recipient mice was performed $3 \mathrm{~h}$ after PBS/LPS injection. Lavage composition was analyzed by flow cytometry in CD19+ single cell population and percentage of cells with distinct membrane label was calculated. Percentage of cells was normalized for input of pooled cells as indicated above. 


\section{Bone Marrow Transplantation}

One week before transplantation, female $\mathrm{LDLR}^{-/-}$mice were housed in filter top cages with neomycin $(100 \mathrm{mg} / \mathrm{L}$; Gibco, Breda, The Netherlands) and polymyxin B sulphate (66104 U/L; Gibco Breda, The Netherlands) in their acidified drinking water. The animals received 6 Gy of total body irradiation twice on consecutive days. Bone marrow isolated from SIRP $\alpha^{\Delta \mathrm{CYT}}$ and wt mice was injected intravenously to rescue the hematopoietic system of the irradiated mice as described previously (34). Briefly, one week before transplantation, female LDLR-/- mice were housed in filter-top cages and provided with acidified water containing neomycin (100mg/l; GIBCO, Breda, The Netherlands) and polymyxin B sulfate $(6 \times 104 \mathrm{U} / \mathrm{l}$; GIBCO). The animals received $2 \times 6$ Gy total body irradiation on two consecutive days. On the second day, bone marrow was isolated from $6 \mathrm{SIRP} \alpha^{\Delta \mathrm{CYT}}$ and $6 \mathrm{wt}$ littermates, and $10^{7}$ cells/mouse were injected intravenously to rescue the hematopoietic system of the irradiated mice. Four weeks after the transplantation, mice were put on a high fat diet $(0.15 \%$ cholesterol, $16 \%$ fat, Arie Blok, The Netherlands) for 10 weeks and level of chimerism was tested (reached $98.76 \% \pm 0.73$ ).

\section{Mouse Blood Parameters}

Blood was withdrawn at the indicated times during high fat diet period and plasma lipid levels were enzymatically measured using ELISA (Sigma Aldrich, Zwijndrecht, The Netherlands).

\section{Atherosclerotic Lession Analysis}

Transplanted animals were sacrificed and isolated hearts were cut perpendicularly to heart axis just below the atrial tips, as described before $(35,36)$. Briefly, tissue was frozen in tissue-tec (Shandon, Veldhoven, The Netherlands) with the base facing downward, and sectioning was performed toward the aortic valve area. Sections of 7 $\mu \mathrm{m}$ were collected, starting from where the atrioventricular valves were visible. Aortic lesion areas were quantified using serial crosssections obtained every $42 \mu \mathrm{m}$, beginning at the start of the atrioventricular valves and spanning $250 \mu \mathrm{m}$. Serial cross sections were stained with toluidin blue and lesion areas were quantified using Adobe Photoshop software. Severity of lesions was scored as early, moderate and advanced, using criteria as described before (35, 36). In detail, early lesions were fatty streaks containing only foam cells; moderate (intermediate) lesions were characterized by the additional presence of a collagenous cap, and advanced lesions showed involvement of the media mostly accompanied by increased collagen content and necrosis of the plaque. Foam cell size within plaques was determined by dividing the size of an allocated foamy macrophage area by the number of macrophages.

\section{Immunohistochemical Staining}

Atherosclerotic lesions from aortic roots were stained with various antibodies to identify neutrophils (NIMP directed against Ly6G, a gift from P. Heeringa), T cells (KT3, directed against CD3) and newly recruited macrophages (ER-MP58, a gift from $\mathrm{P}$. Leenen) followed by detection with biotin labeled rabbit anti-rat antibody and staining with $\mathrm{ABC}$ kit (Vector Labs, Burlingame, CA).

\section{Statistical Analysis}

Statistical analysis was performed using GraphPad Prism version 8.02 (GraphPad Software, San Diego, CA, USA). Data were evaluated by two-tailed student t-test if two columns were compared. If more columns were compared, one-way ANOVA followed by multiple comparison correction was applied.

\section{RESULTS}

\section{SIRP $\alpha$ Is Expressed on B1 Cells}

The inhibitory immunoreceptor SIRP $\alpha$ is considered to be present selectively on neuronal cells as well as on myeloid cells in the hematopoietic compartment $(1,37)$. It is thought to be lacking from lymphoid cells, at least under steady state conditions (38). However, a more detailed evaluation of $\mathrm{B}$ cell subsets revealed SIRP $\alpha$ expression on all $\mathrm{B} 1$ cells in the peritoneal cavity (PC) and on a subpopulation of $\mathrm{B}$ cells in the spleen (SP) of mice (Figures 1A-C and Supplementary Figures 1A, B). In particular, by using specific markers identifying B1a cells (i.e., $\mathrm{CD} 19^{+} \mathrm{CD} 5^{+} \mathrm{CD} 11 \mathrm{~b}^{+}$) and $\mathrm{B} 1 \mathrm{~b}$ cells (i.e., $\mathrm{CD} 19^{+} \mathrm{CD} 5^{-} \mathrm{CD} 11 \mathrm{~b}^{+}$) we could clearly demonstrate surface SIRP $\alpha$ expression on both of these PC B1 lymphocyte populations. PC B2 cells show much lower if any SIRP $\alpha$ expression. In the spleen we could detect expression of SIRP $\alpha$ only on a subset of $\mathrm{B} 220^{+} / \mathrm{CD} 19^{+} \mathrm{CD} 43^{+} \mathrm{CD} 23^{-} \mathrm{B} 1$ cells. Relatively low levels of SIRP $\alpha$ staining were found on marginal zone B cells $\left(\mathrm{B} 220^{+} / \mathrm{CD} 19^{+} \mathrm{CD} 43^{-} \mathrm{CD} 23^{-}\right)$and minimal detectable expression was found on $\mathrm{B} 220^{+} / \mathrm{CD} 19^{+} \mathrm{CD} 23^{+} \mathrm{CD} 43^{-}$follicular $\mathrm{B}$ cells. Consistent with other studies (38), we could not observe any SIRP $\alpha$ expression on circulating B cells in mice and no expression on B2 cells from the bone marrow (Supplementary Figure 1C). However, we could detect SIRP $\alpha$ on fetal liver B220 ${ }^{+} \mathrm{CD} 19^{+} \mathrm{CD} 43^{+}$ $\mathrm{B}$ cells and B1 cells in the bone marrow (Supplementary Figure 1C). As a control staining was performed on B1 cells from the peritoneal cavity of mice deficient for SIRP $\alpha$ altogether $\left(\operatorname{SIRP} \alpha^{-1-}\right.$ mice, Supplementary Figure 2) indicating that staining observed on B1 cells in wild type mice can indeed be solely attributed to SIRP $\alpha$ expression on those cells. Staining on B1 cells from SIRP $\alpha^{\Delta C Y T}$ mice showed a slightly reduced overall surface expression as has been reported for other cells expressing SIRP $\alpha$ (data not shown). Compared with peritoneal macrophages, we found substantially lower levels of both CD11b and SIRP $\alpha$ on B1 cells, clearly discriminating B1 cells from myeloid cells (Figure 1D). Expression of SIRP $\alpha$ mRNA was confirmed by qRT-PCR on FACS sorted peritoneal B1a cells $\left(\mathrm{CD} 19^{+} \mathrm{CD}^{+} \mathrm{CD} 11 \mathrm{~b}^{+}\right)$(Figure 1E).

\section{SIRP $\alpha$ Limits Natural IgM Antibody Levels In Vivo}

Because SIRP $\alpha$, like Siglec-G, is also a typical inhibitory immunoreceptor with cytoplasmic ITIM motifs signaling through SHP-1 and/or SHP-2, we tested whether the lack of SIRP $\alpha$ signaling would affect natural antibody generation as well. As can be seen in Figure 2A there was a prominent $(\sim 2$-fold $)$ enhancement in the plasma levels of total and OSE-reactive natural IgM antibodies in mice lacking the cytoplasmic tail of $\operatorname{SIRP} \alpha\left(\operatorname{SIRP} \alpha^{\Delta \mathrm{CYT}}\right.$ mice). This occurred for all OSE tested, including the so-called T15 epitope that 
A

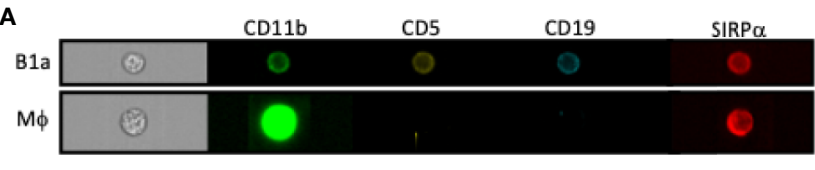

B

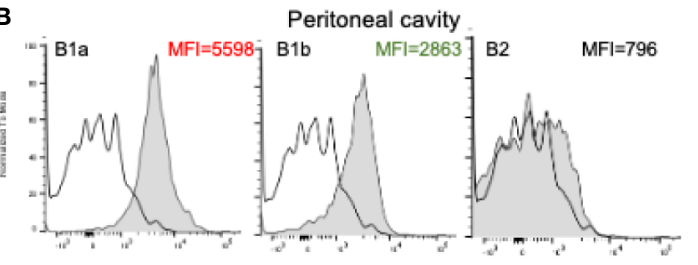

Spleen

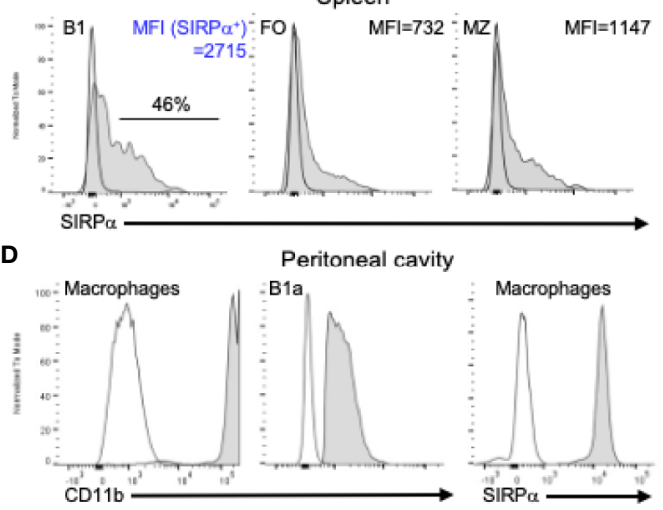

C
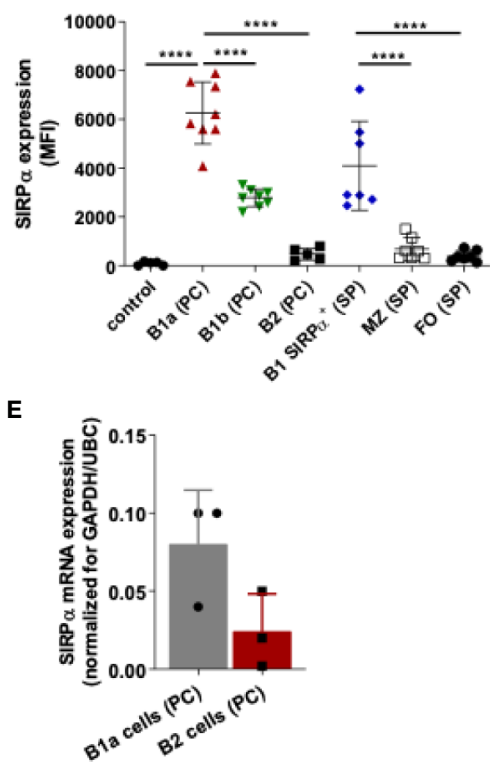

FIGURE 1 | SIRP $\alpha$ is expressed by B1 cells. (A) Imaging flow cytometry visualizing expression of SIRP $\alpha$ on CD19+CD5+CD11b+ B1a cells and CD11b+CD19macrophages. Representative histograms (B) and synopsis (C) of SIRP $\alpha$ surface expression on defined B cell subpopulations as determined by flow cytometry (MFI, Mean fluorescence intensity). Note that the most prominent expression occurs on peritoneal cavity (PC) B1a and B1b cells, and on a subset of the splenic (SP) B1, with little or no expression on marginal zone (MZ) and follicular (FO) B cells. (D) Macrophages cells from the peritoneal cavity show relatively high levels of expression of both CD11b and SIRP $\alpha$. (E) SIRP $\alpha$ mRNA expression on FACS sorted peritoneal cavity B1a and B2 cells. Data are in (C, E) are presented as mean \pm SEM and represent measurements of 5-8 and 3 individual mice, respectively. Statistical analysis was performed by one-way ANOVA with Dunnett's multiple comparison corrrection, ${ }^{* * * *} \mathrm{p}<0.0001$.

defines PC-reactive EO6 type anti-OxLDL IgM antibodies with anti-atherogenic potential in vivo $(11,39)$, as well as phosphocholine (PC) and those against ex vivo oxidized LDL (i.e., MDA-LDL and $\mathrm{Cu}-\mathrm{OxLDL})$. Consistent with a specific B1 cell phenotype and a selective regulation of natural IgM levels the corresponding IgG levels were not altered (Figure 2B). When SIRP $\alpha^{\Delta C Y T}$ mice were immunized with a typical T-cell independent type 2 (TI-2) antigen, DNP-Ficoll, we observed robust and enhanced DNP-specific IgM and IgG3 immune responses (Figure 2C). Of interest, no enhanced antibody responses have been observed in SIRP $\alpha^{\Delta C Y T}$ mice upon immunization with the thymus-dependent antigen TNP-KLH (Y. Kaneko (Gunma University, Japan), personal communication). These results indicate that SIRP $\alpha$ signaling regulates natural antibody production as well as the response of $\mathrm{B} 1$ cells to antigenic stimulation.

\section{SIRP $\alpha$ Increases Splenic B1 Cell Numbers Without Affecting B Cell Receptor Function}

Next, we investigated whether the changes in B1-cell associated antibodies in SIRP $\alpha^{\Delta \mathrm{CYT}}$ mice could be related to changes in B1 cell numbers in the peritoneal cavity or the spleen of these mice
(Figure 2D, Supplementary Figures 3A-G). We did not detect significant differences in proportions or the absolute numbers of peritoneal cavity $\mathrm{B} 1 \mathrm{a}$ and $\mathrm{B} 1 \mathrm{~b}$ cells. In contrast, proportions and absolute numbers of $\mathrm{B} 1$ cells in the spleen of SIRP $\alpha^{\Delta \mathrm{CYT}}$ mice were significantly ( 2-fold) increased compared to wt animals. There were no significant differences in total cell numbers or proportions of other splenic B cell subsets, indicating that the effects were specific for B1 cells. We next asked how SIRP $\alpha$ might contribute to the increase in splenic B cell numbers and natural antibody levels. One possibility was that SIRP $\alpha$ was controlling the activation and expansion of B1 cells. First, we tested whether antigen recognition by $\mathrm{B} 1$ cells might be altered, as a consequence of potential differences in BCR expression, but we observed no difference in, e.g., the binding of a typical B1a cell antigen phosphatidylcholine (PtC) (40) to Bla cells (Figure 3A and Supplementary Figure $\mathbf{3 H}$ ). Next, we explored potential differences in B1a cell activation capacity. This included measuring $\mathrm{Ca}^{2+}$ flux upon cross-linking of BCR (Figure 3B), and monitoring sorted PC B1a cell IgM secretion upon stimulation with LPS in vitro (Figure 3C), a potent and typical B1 cell activation stimulus (7). Both read-outs showed comparable activation capacity of wt and SIRP $\alpha^{\Delta C Y T}$ B1a cells. 
A

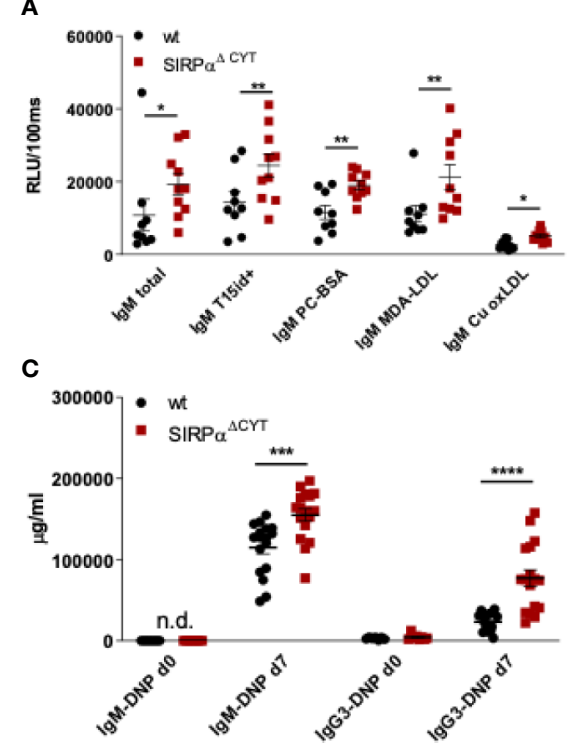

B

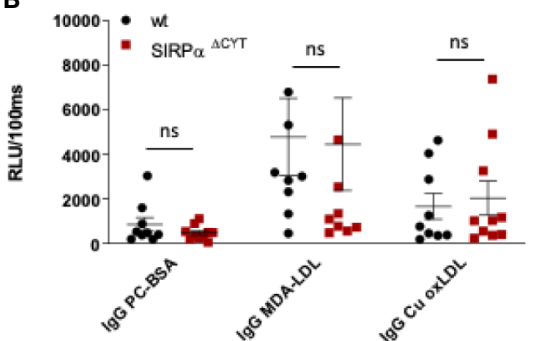

D

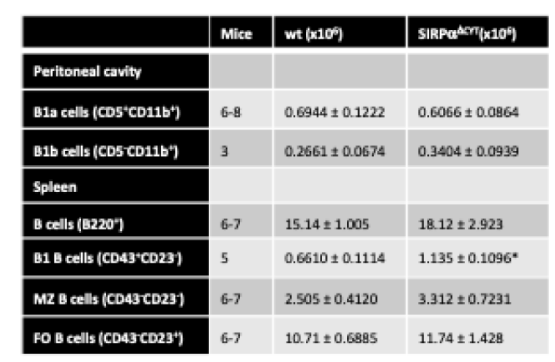

FIGURE 2 | Loss of SIRP $\alpha$ signaling promotes B1 cell accumulation in the spleen and natural lgM antibody formation in vivo. Defective SIRP $\alpha$ signaling in mice lacking the SIRP $\alpha$ cytoplasmic tail (SIRP $\alpha^{\Delta \mathrm{CYT}}$ ) results in increased plasma levels of natural lgM (A) but not lgG (B) antibodies directed against the indicated oxidation-specific epitopes under steady-state conditions; wt, wild-type mice; RLU/100 ms, Relative Luminescence per 100 ms. (C) Immunization with the haptenated TI-2 antigen DNP-Ficoll triggers increased production of both IgM and IgG3 antibodies against DNP in SIRP $\alpha^{\Delta C Y T}$ mice. Data are presented as mean \pm SEM and are representative of 9-10 (A), 8 (B), 17 (C) individual mice. (D) B cell numbers in peritoneal cavity and spleen of wt and SIRP $\alpha^{\Delta C Y T}$ mice. Absolute number of different B cell populations was determined in the peritoneal cavity and the spleen of young adult mice (8-12 weeks) under steady state conditions. For further details see Supplementary Figures 2A-G. Statistical analysis was performed by unpaired Student t-test, corrected for multiple comparisons with Holm-Sedak method where applicable, ${ }^{\star} p<0.05 ;{ }^{\star \star} p<0.01,{ }^{\star \star \star} p<0.001,{ }^{\star \star \star \star} p<0.0001$.; ns, non-significant; n.d., not detectable.

Finally, there were apparently no differences in B1a cell proliferation (Supplementary Figure 4). Taken together, these findings support the idea that SIRP $\alpha$ signaling controls splenic B1 cell accumulation and, likewise as a consequence, also the levels of naturally occurring antibodies, but this was apparently not linked to a generalized regulation of BCR- or TLR-mediated B1 cell activation.

\section{SIRP $\alpha$ Regulates CD11b/CD18 Integrin Function and B1 Cell Migratory Capacity}

Notably, when analyzing LPS-stimulated B1 cells by flow cytometry, we observed the presence of cell clusters in the cultures that appeared larger for SIRP $\alpha^{\Delta C Y T}$ B1a cells relative to their wt counterparts (Supplementary Figure 5A). This prompted us to visualize and quantify this aggregate formation of Bla cells by imaging flow cytometry, which indeed consistently demonstrated a substantially increased proportion of large aggregates (i.e., consisting of more than 4 cells) in SIRP $\alpha^{\Delta C Y T}$ peritoneal B1a cells as compared to wt B1a cells after LPS stimulation (Figure 4A and Supplementary Figures $\mathbf{5 B}, \mathbf{C})$. In contrary, we could not observe comparable aggregates when sorted splenic B1 cells were cultured in a similar manner (Figure 4B). Interestingly, such doublets and large aggregates specific for $\mathrm{CD}_{1} 1 \mathrm{~b}^{+} \mathrm{B} 1$ cells have been previously reported by Ghosn et al. and their formation seems to be dependent on CD11b (9). Furthermore, SIRP $\alpha$ inhibitory signaling has been previously linked to integrin function in other cells (28). We therefore hypothesized that $\operatorname{SIRP} \alpha$ may serve as a negative regulator of CD11b/CD18 integrin function in B1 cells. To test this, we stimulated sorted peritoneal Bla cells with LPS in the presence of a blocking anti-CD11b antibody. Clearly, the increased formation of large aggregates triggered by LPS in mice lacking SIRP $\alpha$ signaling could be partially prevented by blocking CD11b, but not by blocking CD11a (Figure 4C). Next, we asked whether B1 cell aggregate formation through CD11b/ CD18 integrin could be a prerequisite for production of natural antibodies. We tested supernatants of B1a cells that were activated by LPS in the presence of blocking CD11b antibody or blocking CD11a antibody. It appeared that SIRP $\alpha^{\Delta C Y T}$ B1a cells have comparable antibody production as wt B1 cells in vitro, independently of CD11b or CD11a function (Figure 4D). Thus, whereas CD11b-mediated formation of large aggregates did not regulate natural antibody production in vitro, such B1 cell aggregate formation, which was promoted upon disruption of SIRP $\alpha$ signaling, nevertheless appeared a read-out for CD11b/ CD18 activation. This suggested that SIRP $\alpha$ signaling was negatively regulating $\mathrm{B} 1$ cell integrin function. Of interest, Waffarn et al. have shown, that CD11b/CD18, unlike CD11a/ CD18, is indispensable for migration of stimulated B1 cells from cavities to secondary lymphoid tissues where they mature into natural antibody producing plasma cells (8). This led us to propose that SIRP $\alpha$ could actually regulate CD11b/CD18 function during migration of $\mathrm{B} 1$ cells to the secondary lymphoid tissues, which would provide an explanation for the 
A

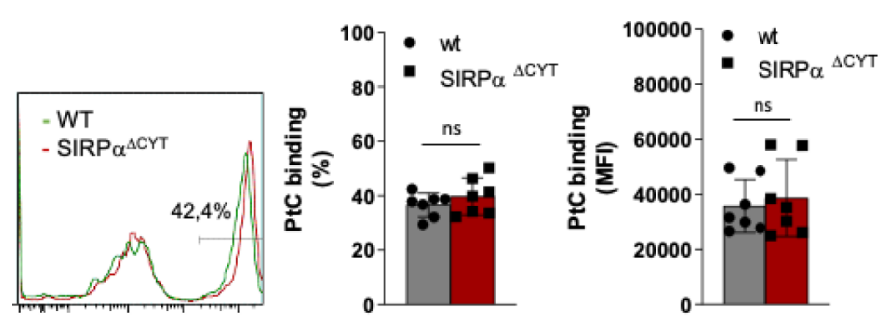

B
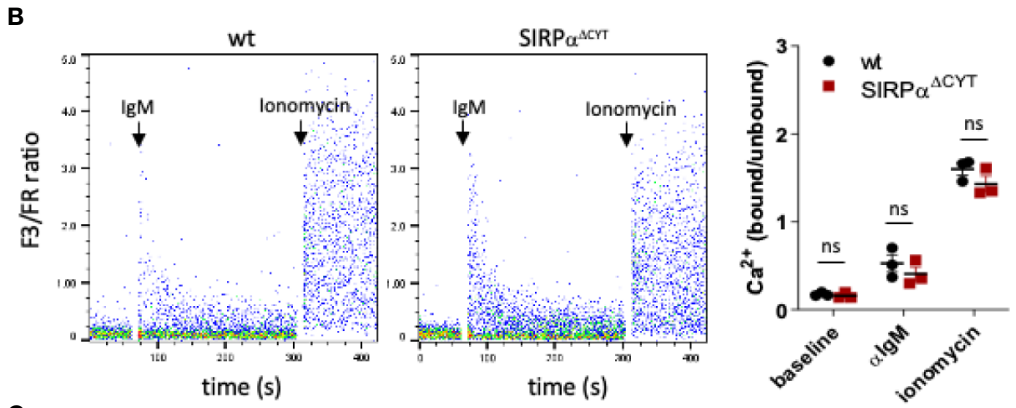

C

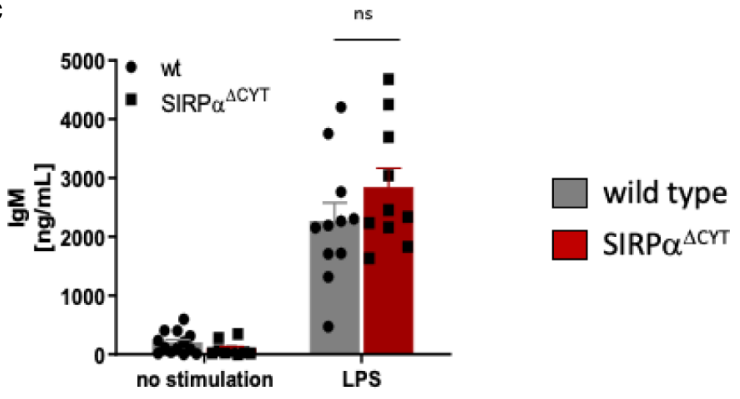

FIGURE 3 | Loss of SIRP $\alpha$ signaling does not have a generalized effect on B1 cell activation. (A) Comparable frequency (FACS plot of representative example, left panel; \% positivity, middle panel) and magnitude (MFI, right panel) of phosphatidylcholine (PtC; a typical B1a antigen) antigen binding by $w^{\prime}$ and SIRP $\alpha^{\Delta C Y T}$ peritoneal

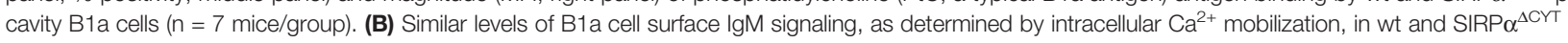
peritoneal cavity B1 cells triggered by anti-lgM antibodies; responses with ionomycin are shown as a positive control; left panels: representative examples of $\mathrm{Ca}^{2+}$-responses in wt and SIRP $\alpha^{\Delta \mathrm{CYT}}$ (B); right panels: average values of B1a cells from $\mathrm{n}=3$ mice/group. (C) Comparable levels of LPS-stimulated lgM production in B1a cells isolated from SIRP $\alpha^{\Delta C Y T}$ and wt mice ( $n=10-11$ mice/group); $n s$, non-significant.

increased numbers of B1 cells in the spleens of SIRP $\alpha^{\Delta C Y T}$ mice. To directly test the effect of SIRP $\alpha$ signaling on the capacity of B1 cells to migrate from the peritoneal cavity we performed adoptive transfer experiments. To confirm integrin-dependence, B1 cells of both wt and SIRP $\alpha^{\Delta \mathrm{CYT}}$ donor mice were in parallel preincubated with blocking CD11b antibody, excessive amount of the antibody was removed, and then, the cells were labeled with unique membrane dyes, mixed in 1:1 ratio, and injected to either wt or SIRP $\alpha^{\Delta C Y T}$ recipients (Figure $4 \mathbf{E}$ ). This set-up allowed us to selectively monitor, in individual animals, the effect of SIRP $\alpha$ and $\mathrm{CD} 1 \mathrm{~b} / \mathrm{CD} 18$ on the migration of $\mathrm{B} 1$ cells from the peritoneal cavity to the spleen. As expected, B1 cells that lack inhibitory cytoplasmic tail of SIRP $\alpha$ showed increased efflux from the peritoneal cavity (Figure $\mathbf{4 F}$ ). The enhanced exit of SIRP $\alpha^{\Delta C Y T} B 1$ cells was fully dependent on CD11b/CD18, as it could be completely inhibited by antibody blocking. Taken together, our data strongly suggest that CD11b/CD18 function in B1 cells is under negative control of SIRP $\alpha$ and that in absence of SIRP $\alpha$ signaling B1 cells have a higher propensity to leave the peritoneal cavity, thereby contributing to an accumulation of B1 cells in the spleen and an enhanced systemic production of natural antibodies.

\section{Lack of SIRP $\alpha$ Signaling Protects Mice From Atherosclerosis}

In order to further establish the potential pathological/clinical relevance of the regulation of natural IgM antibody production by SIRP $\alpha$ in vivo, we decided to explore the role of SIRP $\alpha$ in atherosclerosis. Natural IgM antibodies produced by B1a cells have a well-established protective role in various diseases, and particularly in atherosclerosis, a feature which is apparently due to their capacity to neutralize oxLDL uptake and enhance apoptotic cell clearance by macrophages (11-13). To directly address the role of SIRP $\alpha$ in atherosclerosis in mice, we transplanted wt and SIRP $\alpha^{\Delta C Y T}$ bone marrow into atherosclerosis-prone LDLR $^{-/-}$ recipient mice. This well-established atherosclerosis model includes the replacement of peritoneal B cell populations (including B1 cells) by the donor cells (11, 12, 21, 22, 41-43). 
A
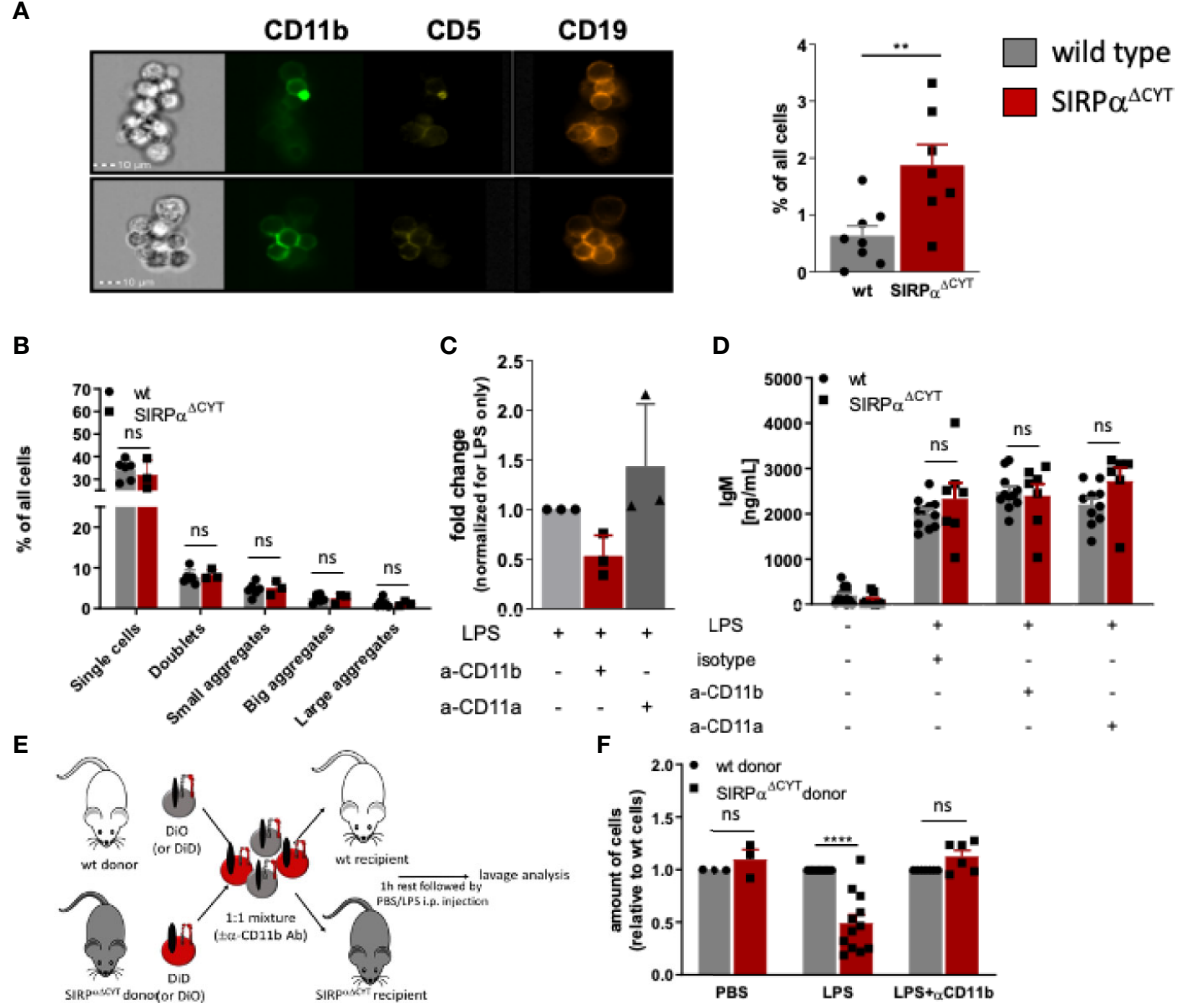

D

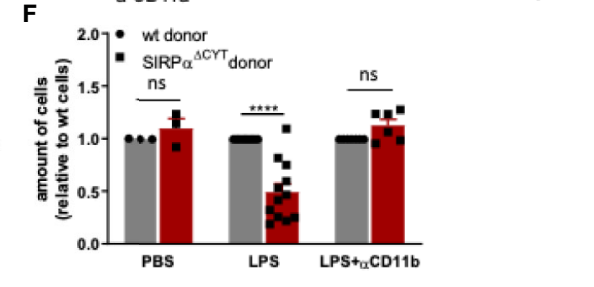

FIGURE 4 | Loss of SIRP $\alpha$ signaling promotes LPS-induced CD11b/CD18 integrin-dependent B1 cell efflux from the peritoneal cavity. (A, B) Lack of SIRP $\alpha$ signaling promotes the formation of large aggregates in isolated SIRP $\alpha^{\Delta C Y T}$ peritoneal cavity (A) but not splenic (B) B1a cells $(n=6-8$ mice/group). (C) Enhanced frequency of $\mathrm{B} 1$ cell large aggregates in SIRP $\alpha^{\Delta C Y T}$ peritoneal cavity B1a cells relative to wt cells is CD11b/CD18-integrin-dependent as it is reduced by blocking anti-CD11b, but not anti-CD11a antibodies. (D) Blockade of CD11b/CD18 or CD11a/CD18 integrins has no effect on IgM antibody production by peritoneal cavity B1 cells upon LPS stimulation. (E) Experimental design of egress of adoptively transferred mixed SIRP $\alpha^{\Delta C Y T} /$ wt B1 cells from the peritoneal cavity. (F) Evaluation of adoptively transferred mixed SIRP $\alpha^{\Delta C Y T} / w t$ B1 cells shows increased efflux of SIRP $\alpha^{\Delta C Y T}$ B1 cells relative to wt from the peritoneal cavity upon LPS stimulation and this enhanced egress is CD11b/CD18 dependent ( $n=3-12$ mice/group). Similar data were obtained for SIRP $\alpha^{\Delta C Y T}$ recipients (not shown). Data are presented as mean \pm SEM. Statistical analysis was performed by unpaired Student t-test, corrected for multiple comparisons with Holm-Sedak method where applicable, ${ }^{* *} \mathrm{p}<$ $0.01,{ }^{\star \star \star \star} \mathrm{p}<0.0001 ; \mathrm{ns}$, non-significant.

Mice transplanted with wt or SIRP $\alpha^{\Delta \mathrm{CYT}}$ cells, and subjected to a high-fat diet, showed neither differences in weight, plasma cholesterol and triglyceride levels nor prominent changes in blood cell composition (Supplementary Figures 6A-E). However, when the atherosclerotic lesions of these mice were evaluated, it became apparent that mice transplanted with SIRP $\alpha^{\Delta \mathrm{CYT}}$ cells developed much smaller lesions (Figure 5A) with a substantially less severe phenotype (Figure 5B) compared to wt chimeras. Additionally, when the plasma of atherosclerotic mice was analyzed for the presence of antibodies against oxLDL, in mice transplanted with SIRP $\alpha^{\Delta C Y T}$ cells elevated levels of T15/E06 IgM (Figure 5C), an oxLDL neutralizing antibody, being particularly critical in the protection against atherosclerosis, were found. $(11,39,44)$. Similar to the steady state situation, levels of IgG targeting OSE remained unaltered (Supplementary Figure 6F). A more detailed evaluation of the cellular composition of the lesions showed an increase in the number of newly recruited ERMP58+ myeloid cells (Figure 5D), which was associated with a significantly decreased mRNA for $\mathrm{CD} 8^{+}$macrophages (Figure 5E) and size of the area occupied by foam cells in mice transplanted with SIRP $\alpha^{\Delta C Y T}$ cells (Figure 5F), consistent with the proposed mechanism of IgM-mediated inhibition of foam cell formation $(11,16,45)$. There were no significant differences observed in numbers of other immune cells known to be involved in pathogenesis of atherosclerosis, such as Tlymphocytes and neutrophils (Supplementary Figures 6G, H).

\section{DISCUSSION}

In this study, we provide evidence for the expression and functional relevance of the inhibitory receptor SIRP $\alpha$ on B1 cells in mice. Our results demonstrate that SIRP $\alpha$ is an inhibitory receptor on B1 cells that controls the numbers of splenic B1 cells, thereby most likely affecting systemic natural antibody levels. The increase in splenic B1 cell numbers in the absence of SIRP $\alpha$ signaling occurs most probably because of the absence of an inhibitory effect of on CD11b/CD18 integrin activation, which promotes the migration of these $\mathrm{B} 1$ cells from the peritoneal cavity to the spleen. We also show that a lack of 


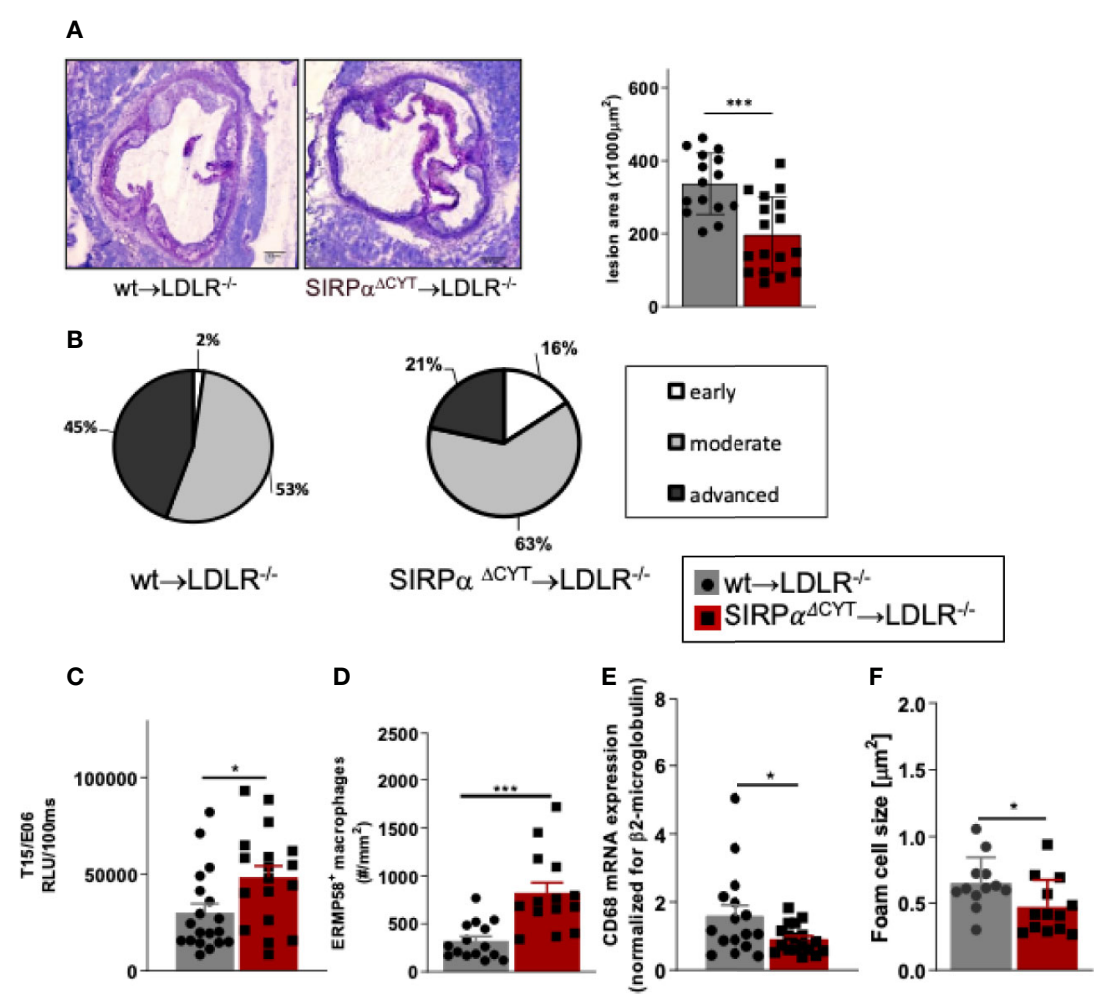

FIGURE 5 | Loss of SIRP $\alpha$ signaling protects mice from atherosclerosis. (A, B) Bone marrow chimeras carrying dysfunctional SIRP $\alpha$ in their hematopoietic compartment are protected from atherosclerosis, showing (A) smaller and (B) less severe aortic lesions. (C) Atheroprotection in $S I R P \alpha^{\Delta C Y T}>L D L R^{-/-}$chimeras is associated with increased levels of oxLDL-targeting natural antibody T15/E06 in plasma. (D-F) Atherosclerotic lesions of SIRP $\alpha^{\Delta C Y T}>L_{D L R}{ }^{-/-}$chimeras contain more small macrophages (D), less CD68+ macrophages (E), and a smaller foam cell area (F) as compared to wt chimeras. Data are presented as mean \pm SEM and are representative of 15-17 (A, B), 18-19 (C), and 12-16 (D-F) individual mice. Statistical analysis was performed by unpaired Student t-test used per variable, corrected for multiple comparisons with Holm-Sedak method, ${ }^{*} p<0.05 ;{ }^{* \star *} p<0.001$ or Chi-square test (B), ${ }^{\star} p<0.05$.

inhibitory SIRP $\alpha$ signaling in atherosclerotic mice leads to selectively elevated plasma levels of oxLDL-neutralizing natural antibodies and propose that this directly contributes to the atheroprotective effect of SIRP $\alpha$ mutation. The latter is in agreement with the well-established regulatory role of such antibodies in atherosclerosis (46).

SIRP $\alpha$ is one of the most abundant inhibitory receptors on myeloid cells including neutrophils, monocytes, the majority of tissue macrophages and $\mathrm{CD}^{+}$dendritic cells, affecting a variety of cell functions in a primarily negative fashion $(1,2) \cdot \operatorname{SIRP} \alpha$ has, as yet, not been reported to be expressed by any B cells. Recently, SIRP $\alpha$ was also reported to be selectively expressed on a small subset of $\mathrm{T}$ lymphocytes, i.e., exhausted CD8+ memory $\mathrm{T}$ cells emerging after chronic viral infection (47). For a long time, the general assumption has been that SIRP $\alpha$ is, at least among hematopoietic cells, restricted to the myeloid lineage $(37,48)$. Most of the studies based the absence of SIRP $\alpha$ from lymphocytes on staining of blood cells in rodents (37, 38) while other, less accessible or more obscure subpopulations of lymphoid origin remained unexplored. We found expression of SIRP $\alpha$ exclusively on $\mathrm{B} 1$ cells in the peritoneal cavity and on a minor subset of B cells in the spleen. We also observed that the population of steady-state splenic B1 cells is roughly doubled in mice lacking SIRP $\alpha$ signaling. This increase in splenic B1 cells may well explain the (also $\sim 2$-fold) higher IgM plasma levels found in
SIRP $\alpha^{\Delta C Y T}$ mice. Antigens with repetitive patterns, such as lipids and glycolipids, including self-antigens that are generated, e.g., upon oxidation or apoptosis can induce multivalent antigen crosslinking of specific BCR on B1 cells and induce TI-2 responses. Due to this selfand poly- reactivity of $\mathrm{B} 1$ cells, their functions have to be tightly regulated to avoid autoimmunity. Several inhibitory receptors that regulate various aspects of $\mathrm{B} 1$ cell function are already known to be instrumental in this. We have observed that lack of SIRP $\alpha$ on B1 cells has no measurable effect on calcium flux and IgM secretion, which may suggest that Siglec-G and CD5, which have previously shown to regulate these parameters, comprise the major regulators of $\mathrm{BCR}$ signaling in $\mathrm{B} 1$ cells (17). SIRP $\alpha^{\Delta \mathrm{CYT}}$ mice have moderately increased numbers of B1 cells only in the spleen with the peritoneal population virtually unaltered. Also, B1-associated antibody levels are elevated in SIRP $\alpha^{\Delta \mathrm{CYT}}$ mice, both at baseline and after TI-2 antigen exposure. Natural antibodies are predominantly produced by B1 cells in secondary lymphoid organs such as spleen (4) or specific (e.g., mediastinal) lymph nodes (8). Egress of B1 cells residing in the body cavities (peritoneal or pleural) into the secondary lymphoid organs has been demonstrated to depend on the CD11b/CD18 integrin (8). CD11b can function only in heterodimer with CD18 integrin, forming together CD11b/CD18 (also known as CR3, Mac-1, 
Integrin alpha $\mathrm{M}$, or $\alpha_{M} \beta_{2}$ integrin). $\mathrm{B} 1$ cells are known to express various integrin molecules, but B1 cells are the only B cells that express CD11b/CD18 integrin and until now no direct regulator of its function has been described. We show here that SIRP $\alpha$ negatively regulates capacity of $\mathrm{B} 1$ cells to exit the peritoneal cavity through CD11b/CD18 integrin, identifying this inhibitory immunoreceptor as the first bona fide regulator of B1 migratory function. It should be emphasized that we cannot formally attribute the in vivo phenotype of the SIRP $\alpha$-mutant mice to B1 cell-intrinsic effects of SIRP $\alpha$ signaling, since also other cells, such as myeloid cells, in these mice have a defect in SIRP $\alpha$ signaling as well. Taken together, a picture emerges where different B1 cell functions appear to be regulated by distinct inhibitory receptors, with SIRP $\alpha$ more or less specifically controlling their migratory behavior, whereas others, e.g., Siglec-G and CD5 may control B1 cell activation in a more generalized fashion.

The homeostatic function of IgM antibodies has been well documented in atherosclerosis (11-13, 49). Mice lacking SIRP $\alpha$ signaling in the hematopoietic compartment showed increased plasma levels of T15/E06 IgM and show smaller and less severe atherosclerotic lesions. This is consistent with observations in Siglec $\mathrm{G}^{-/-}$bone marrow chimeras, where the lack of inhibitory signaling by Siglec G led to increased OSE-specific natural IgM antibody levels and decreased atherosclerosis development (24). Increased plasma level of T15/E06 IgM is a very likely mechanism of atheroprotection in $\operatorname{SIRP} \alpha^{\Delta C Y T}$ chimeras. However, transplantation of SIRP $\alpha^{\Delta \mathrm{CYT}}$ and wt bone marrow resulted in replacement of both myeloid and lymphoid lineage in the donor $\mathrm{LDLR}^{-/-}$mice. As macrophages are important players in development of atherosclerosis we cannot exclude their contribution to the observed phenotype, especially since the SIRP $\alpha$ counter-receptor CD47 appears involved in pathogenesis of atherosclerosis through inhibition, e.g., macrophage efferocytosis (50). Furthermore, whether blocking antibodies targeting SIRP $\alpha$, rather than CD47, would show similar effect still remains to be confirmed, also because the CD47 monoclonal antibody miap410 used in the study of Kojima (50) has prominent opsonizing capacity and a less convincing ability to actually block the CD47-SIRP $\alpha$ axis (51).

Importantly, it is well established that humans, like mice, have "natural" antibodies targeting, e.g., OSE, which are atheroprotective, and these even appear to have prognostic value for the development of cardiovascular disease (52). Based on our current findings in mice, the prediction would therefore be that the human natural antibody producing B cells would also express SIRP $\alpha$ and would consequently also be subject to regulation via the CD47-SIRP $\alpha$ axis. The problem is, however, that the B1 cell equivalent subset responsible for natural antibody production in humans has not been properly identified, and this is in fact a heavily debated issue in the B1 cell field. For instance, the reported identification of human B1 cells in blood defined as $\mathrm{CD} 20^{+} \mathrm{CD} 27^{+} \mathrm{CD} 43^{+} \mathrm{CD} 70^{-}$(53) is quite controversial and has been challenged by several other studies suggesting that these cells are rather result of a technical artefact (54-56). Further studies are clearly needed to resolve this issue and to establish SIRP $\alpha$ expression and function on these putative human B1 cells.

Collectively, our data identify SIRP $\alpha$ as a novel B1 cell immune checkpoint, which functions to control B1 cell migration to lymphoid tissues and natural antibody generation. Our findings also imply SIRP $\alpha$ as a potential therapeutic target in atherosclerosis. The CD47-SIRP $\alpha$ innate immune checkpoint is currently extensively studied in the context of cancer immunotherapy (2, 57 ), with a number of different agents in preclinical and/or clinical development, and $\sim 35$ ongoing clinical trials, carving out a path for potential therapeutic targeting of the CD47-SIRP $\alpha$ axis also in other diseases, including cardiovascular disease.

\section{AUTHOR'S NOTE}

This manuscript has been released as a preprint at BioRxiv, doi: https://doi.org/10.1101/2020.05.13.092494.

\section{DATA AVAILABILITY STATEMENT}

The raw data supporting the conclusions of this article will be made available by the authors, without undue reservation.

\section{ETHICS STATEMENT}

The animal study was reviewed and approved by Animal Welfare Committees of the VU Medical Center Amsterdam, The Netherlands; Maastricht University, Maastricht, The Netherlands; and The Netherlands Cancer Institute, Amsterdam, The Netherlands.

\section{AUTHOR CONTRIBUTIONS}

KF, SP, MH, MG, HM, JG, HO, CP, PG, MO-K, and YS performed experiments and analyzed data. TM, TK, RH, GK, CB, MW, and TB provided reagents and facilities and designed research and/or evaluated data. KF and TB wrote the paper. All authors contributed to the article and approved the submitted version.

\section{FUNDING}

This work was supported by NWO-TOP grant (\#91208001) awarded to GK, MW, and TB.

\section{ACKNOWLEDGMENTS}

The authors thank Martijn A. Nolte and Rene A.W. van Lier for useful discussions.

\section{SUPPLEMENTARY MATERIAL}

The Supplementary Material for this article can be found online at: https://www.frontiersin.org/articles/10.3389/fimmu.2020. 570963/full\#supplementary-material 


\section{REFERENCES}

1. Barclay AN, van den Berg TK. The interaction between signal regulatory protein alpha (SIRPalpha) and CD47: structure, function, and therapeutic target. Annu Rev Immunol (2014) 32:25-50. doi: 10.1146/annurev-immunol032713-120142

2. Matlung HL, Szilagyi K, Barclay NA, van den Berg TK. The CD47-SIRPalpha signaling axis as an innate immune checkpoint in cancer. Immunol Rev (2017) 276(1):145-64. doi: 10.1111/imr.12527

3. Advani R, Flinn I, Popplewell L, Forero A, Bartlett NL, Ghosh N, et al. CD47 Blockade by Hu5F9-G4 and Rituximab in Non-Hodgkin's Lymphoma. $N$ Engl J Med (2018) 379(18):1711-21. doi: 10.1056/NEJMoa1807315

4. Baumgarth N. The double life of a B-1 cell: self-reactivity selects for protective effector functions. Nat Rev Immunol (2011) 11(1):34-46. doi: 10.1038/nri2901

5. Choi YS, Dieter JA, Rothaeusler K, Luo Z, Baumgarth N. B-1 cells in the bone marrow are a significant source of natural IgM. Eur J Immunol (2012) 42 (1):120-9. doi: 10.1002/eji.201141890

6. Smith FL, Baumgarth N. B-1 cell responses to infections. Curr Opin Immunol (2019) 57:23-31. doi: 10.1016/j.coi.2018.12.001

7. Yang Y, Tung JW, Ghosn EE, Herzenberg LA, Herzenberg LA. Division and differentiation of natural antibody-producing cells in mouse spleen. Proc Natl Acad Sci U S A (2007) 104(11):4542-6. doi: 10.1073/pnas.0700001104

8. Waffarn EE, Hastey CJ, Dixit N, Soo Choi Y, Cherry S, Kalinke U, et al. Infection-induced type I interferons activate CD11b on B-1 cells for subsequent lymph node accumulation. Nat Commun (2015) 6:8991. doi: $10.1038 /$ ncomms 9991

9. Ghosn EE, Yang Y, Tung J, Herzenberg LA, Herzenberg LA. CD11b expression distinguishes sequential stages of peritoneal B-1 development. Proc Natl Acad Sci U S A (2008) 105(13):5195-200. doi: 10.1073/ pnas.0712350105

10. Miller YI, Tsimikas S. Oxidation-specific epitopes as targets for biotheranostic applications in humans: biomarkers, molecular imaging and therapeutics. Curr Opin Lipidol (2013) 24(5):426-37. doi: 10.1097/MOL.0b013e328364e85a

11. Binder CJ, Horkko S, Dewan A, Chang MK, Kieu EP, Goodyear CS, et al. Pneumococcal vaccination decreases atherosclerotic lesion formation: molecular mimicry between Streptococcus pneumoniae and oxidized LDL. Nat Med (2003) 9(6):736-43. doi: 10.1038/nm876

12. Caligiuri G, Khallou-Laschet J, Vandaele M, Gaston AT, Delignat S, Mandet C, et al. Phosphorylcholine-targeting immunization reduces atherosclerosis. J Am Coll Cardiol (2007) 50(6):540-6. doi: 10.1016/j.jacc.2006.11.054

13. Faria-Neto JR, Chyu KY, Li X, Dimayuga PC, Ferreira C, Yano J, et al. Passive immunization with monoclonal IgM antibodies against phosphorylcholine reduces accelerated vein graft atherosclerosis in apolipoprotein E-null mice. Atherosclerosis (2006) 189(1):83-90. doi: 10.1016/j.atherosclerosis.2005. 11.033

14. Grasset EK, Duhlin A, Agardh HE, Ovchinnikova O, Hagglof T, Forsell MN, et al. Sterile inflammation in the spleen during atherosclerosis provides oxidation-specific epitopes that induce a protective B-cell response. Proc Natl Acad Sci U S A (2015) 112(16):E2030-8. doi: 10.1073/pnas.1421227112

15. Libby P, Ridker PM, Hansson GK. Progress and challenges in translating the biology of atherosclerosis. Nature (2011) 473(7347):317-25.

16. Horkko S, Bird DA, Miller E, Itabe H, Leitinger N, Subbanagounder G, et al. Monoclonal autoantibodies specific for oxidized phospholipids or oxidized phospholipid-protein adducts inhibit macrophage uptake of oxidized lowdensity lipoproteins. J Clin Invest (1999) 103(1):117-28. doi: 10.1172/JCI4533

17. Bikah G, Carey J, Ciallella JR, Tarakhovsky A, Bondada S. CD5-mediated negative regulation of antigen receptor-induced growth signals in B-1 B cells. Science (1996) 274(5294):1906-9. doi: 10.1126/science.274.5294.1906

18. Nitschke L, Carsetti R, Ocker B, Kohler G, Lamers MC. CD22 is a negative regulator of B-cell receptor signalling. Curr Biol (1997) 7(2):133-43. doi: 10.1016/s0960-9822(06)00057-1

19. Amezcua Vesely MC, Schwartz M, Bermejo DA, Montes CL, Cautivo KM, Kalergis AM, et al. FcgammaRIIb and BAFF differentially regulate peritoneal B1 cell survival. J Immunol (2012) 188(10):4792-800. doi: 10.4049/ jimmunol.1102070

20. Bagchi-Chakraborty J, Francis A, Bray T, Masters L, Tsiantoulas D, Nus M, et al. B Cell Fcgamma Receptor IIb Modulates Atherosclerosis in Male and
Female Mice by Controlling Adaptive Germinal Center and Innate B1-Cell Responses. Arterioscler Thromb Vasc Biol (2019) 39:1379-89. doi: 10.1161/ ATVBAHA.118.312272

21. Ding C, Liu Y, Wang Y, Park BK, Wang CY, Zheng P, et al. Siglecg limits the size of B1a B cell lineage by down-regulating NFkappaB activation. PloS One (2007) 2(10):e997. doi: 10.1371/journal.pone.0000997

22. Hoffmann A, Kerr S, Jellusova J, Zhang J, Weisel F, Wellmann U, et al. Siglec$\mathrm{G}$ is a B1 cell-inhibitory receptor that controls expansion and calcium signaling of the B1 cell population. Nat Immunol (2007) 8(7):695-704. doi: $10.1038 /$ ni1 480

23. Hayakawa K, Hardy RR, Parks DR, Herzenberg LA. The "Ly-1 B" cell subpopulation in normal immunodefective, and autoimmune mice. $J$ Exp Med (1983) 157(1):202-18. doi: 10.1084/jem.157.1.202

24. Gruber S, Hendrikx T, Tsiantoulas D, Ozsvar-Kozma M, Goderle L, Mallat Z, et al. Sialic Acid-Binding Immunoglobulin-like Lectin G Promotes Atherosclerosis and Liver Inflammation by Suppressing the Protective Functions of B-1 Cells. Cell Rep (2016) 14(10):2348-61. doi: 10.1016/ j.celrep.2016.02.027

25. Smith KG, Clatworthy MR. FcgammaRIIB in autoimmunity and infection: evolutionary and therapeutic implications. Nat Rev Immunol (2010) 10 (5):328-43. doi: 10.1038/nri2762

26. Washio K, Kotani T, Saito Y, Respatika D, Murata Y, Kaneko Y, et al. Dendritic cell SIRP $\alpha$ regulates homeostasis of dendritic cells in lymphoid organs. Genes Cells Devoted Mol Cell Mech (2015) 20(6):451-63. doi: $10.1111 /$ gtc. 12238

27. Yamao T, Noguchi T, Takeuchi O, Nishiyama U, Morita H, Hagiwara T, et al. Negative regulation of platelet clearance and of the macrophage phagocytic response by the transmembrane glycoprotein SHPS-1. J Biol Chem (2002) 277 (42):39833-9. doi: 10.1074/jbc.M203287200

28. Inagaki K, Yamao T, Noguchi T, Matozaki T, Fukunaga K, Takada T, et al. SHPS-1 regulates integrin-mediated cytoskeletal reorganization and cell motility. EMBO J (2000) 19(24):6721-31. doi: 10.1093/emboj/19.24.6721

29. Lekanne Deprez RH, Fijnvandraat AC, Ruijter JM, Moorman AF. Sensitivity and accuracy of quantitative real-time polymerase chain reaction using SYBR green I depends on cDNA synthesis conditions. Anal Biochem (2002) 307 (1):63-9. doi: 10.1016/S0003-2697(02)00021-0

30. Muggen AF, Pillai SY, Kil LP, van Zelm MC, van Dongen JJ, Hendriks RW, et al. Basal $\mathrm{Ca}(2+)$ signaling is particularly increased in mutated chronic lymphocytic leukemia. Leukemia (2015) 29(2):321-8. doi: 10.1038/leu.2014.188

31. Maas A, Dingjan GM, Savelkoul HF, Kinnon C, Grosveld F, Hendriks RW. The X-linked immunodeficiency defect in the mouse is corrected by expression of human Bruton's tyrosine kinase from a yeast artificial chromosome transgene. Eur J Immunol (1997) 27(9):2180-7. doi: 10.1002/ eji. 1830270910

32. Chou MY, Fogelstrand L, Hartvigsen K, Hansen LF, Woelkers D, Shaw PX, et al. Oxidation-specific epitopes are dominant targets of innate natural antibodies in mice and humans. J Clin Invest (2009) 119(5):1335-49. doi: $10.1172 / \mathrm{JCI} 36800$

33. Ha SA, Tsuji M, Suzuki K, Meek B, Yasuda N, Kaisho T, et al. Regulation of B1 cell migration by signals through Toll-like receptors. J Exp Med (2006) 203 (11):2541-50. doi: 10.1084/jem.20061041

34. Goossens P, Gijbels MJ, Zernecke A, Eijgelaar W, Vergouwe MN, dM v, et al. Myeloid type I interferon signaling promotes atherosclerosis by stimulating macrophage recruitment to lesions. Cell Metab (2010) 12(2):142-53. doi: 10.1016/j.cmet.2010.06.008

35. Kanters E, Pasparakis M, Gijbels MJ, Vergouwe MN, Partouns-Hendriks I, Fijneman RJ, et al. Inhibition of NF-kappaB activation in macrophages increases atherosclerosis in LDL receptor-deficient mice. J Clin Invest (2003) 112(8):1176-85. doi: 10.1172/JCI18580

36. Kanters E, Gijbels MJ, van der Made I, Vergouwe MN, Heeringa P, Kraal G, et al. Hematopoietic NF-kappaB1 deficiency results in small atherosclerotic lesions with an inflammatory phenotype. Blood (2004) 103(3):934-40. doi: 10.1182/blood-2003-05-1450

37. Adams S, van der Laan LJ, Vernon-Wilson E, Renardel de LC, Dopp EA, Dijkstra CD, et al. Signal-regulatory protein is selectively expressed by myeloid and neuronal cells. J Immunol (1998) 161(4):1853-9.

38. Sato-Hashimoto M, Saito Y, Ohnishi H, Iwamura H, Kanazawa Y, Kaneko T, et al. Signal regulatory protein alpha regulates the homeostasis of $\mathrm{T}$ 
lymphocytes in the spleen. J Immunol (2011) 187(1):291-7. doi: 10.4049/ jimmunol.1100528

39. Que X, Hung MY, Yeang C, Gonen A, Prohaska TA, Sun X, et al. Oxidized phospholipids are proinflammatory and proatherogenic in hypercholesterolaemic mice. Nature (2018) 558(7709):301-6. doi: 10.1038/ s41586-018-0198-8

40. Berland R, Wortis HH. Origins and functions of B-1 cells with notes on the role of CD5. Annu Rev Immunol (2002) 20:253-300. doi: 10.1146/ annurev.immunol.20.100301.064833

41. Duber S, Hafner M, Krey M, Lienenklaus S, Roy B, Hobeika E, et al. Induction of B-cell development in adult mice reveals the ability of bone marrow to produce B-1a cells. Blood (2009) 114(24):4960-7. doi: 10.1182/blood-200904-218156

42. Holodick NE, Repetny K, Zhong X, Rothstein TL. Adult BM generates CD5+ B1 cells containing abundant N-region additions. Eur J Immunol (2009) 39 (9):2383-94. doi: 10.1002/eji.200838920

43. Jellusova J, Duber S, Guckel E, Binder CJ, Weiss S, Voll R, et al. Siglec-G regulates B1 cell survival and selection. J Immunol (2010) 185(6):3277-84. doi: 10.4049/jimmunol.1001792

44. Binder CJ, Hartvigsen K, Chang MK, Miller M, Broide D, Palinski W, et al. IL5 links adaptive and natural immunity specific for epitopes of oxidized LDL and protects from atherosclerosis. J Clin Invest (2004) 114(3):427-37. doi: 10.1172/JCI200420479

45. Feng X, Zhang Y, Xu R, Xie X, Tao L, Gao H, et al. Lipopolysaccharide upregulates the expression of Fcalpha/mu receptor and promotes the binding of oxidized low-density lipoprotein and its IgM antibody complex to activated human macrophages. Atherosclerosis (2010) 208(2):396-405. doi: 10.1016/ j.atherosclerosis.2009.07.035

46. Binder CJ, Papac-Milicevic N, Witztum JL. Innate sensing of oxidationspecific epitopes in health and disease. Nat Rev Immunol (2016) 16(8):48597. doi: 10.1038/nri.2016.63

47. Myers LM, Tal MC, Torrez Dulgeroff LB, Carmody AB, Messer RJ, Gulati G, et al. A functional subset of $\mathrm{CD} 8(+) \mathrm{T}$ cells during chronic exhaustion is defined by SIRPalpha expression. Nat Commun (2019) 10(1):794. doi: 10.1038/s41467-019-08637-9

48. Brooke GP, Parsons KR, Howard CJ. Cloning of two members of the SIRP alpha family of protein tyrosine phosphatase binding proteins in cattle that are expressed on monocytes and a subpopulation of dendritic cells and which mediate binding to CD4 T cells. Eur J Immunol (1998) 28 (1):1-11. doi: 10.1002/(SICI)1521-4141(199801)28:01<1::AID-IMMU1>3.0. $\mathrm{CO} ; 2-\mathrm{V}$
49. Gronwall C, Silverman GJ. Natural IgM: beneficial autoantibodies for the control of inflammatory and autoimmune disease. J Clin Immunol (2014) 34 Suppl 1:S12-21. doi: 10.1007/s10875-014-0025-4

50. Kojima Y, Volkmer JP, McKenna K, Civelek M, Lusis AJ, Miller CL, et al. CD47-blocking antibodies restore phagocytosis and prevent atherosclerosis. Nature (2016) 536(7614):86-90. doi: 10.1038/nature18935

51. Han X, Sterling H, Chen Y, Saginario C, Brown EJ, Frazier WA, et al. CD47, a ligand for the macrophage fusion receptor, participates in macrophage multinucleation. J Biol Chem (2000) 275(48):37984-92. doi: 10.1074/jbc.M002334200

52. Ravandi A, Boekholdt SM, Mallat Z, Talmud PJ, Kastelein JJ, Wareham NJ, et al. Relationship of IgG and IgM autoantibodies and immune complexes to oxidized LDL with markers of oxidation and inflammation and cardiovascular events: results from the EPIC-Norfolk Study. J Lipid Res (2011) 52(10):182936. doi: 10.1194/jlr.M015776

53. Griffin DO, Rothstein TL. A small CD11b(+) human B1 cell subpopulation stimulates T cells and is expanded in lupus. J Exp Med (2011) 208(13):2591-8. doi: $10.1084 /$ jem.20110978

54. Reynaud CA, Weill JC. Gene profiling of CD11b ${ }^{+}$and CD11b B1 cell subsets reveals potential cell sorting artifacts. J Exp Med (2012) 209(3):433-4. doi: 10.1084/jem.20120402

55. Descatoire M, Weill JC, Reynaud CA, Weller S. A human equivalent of mouse B-1 cells? J Exp Med (2011) 208(13):2563-4. doi: 10.1084/jem.20112232

56. Perez-Andres M, Grosserichter-Wagener C, Teodosio C, van Dongen JJ, Orfao A, van Zelm MC. The nature of circulating CD27+CD43+ B cells. J Exp Med (2011) 208(13):2565-6. doi: 10.1084/jem.20112203

57. van den Berg TK, Valerius T. Myeloid immune-checkpoint inhibition enters the clinical stage. Nat Rev Clin Oncol (2019) 16(5):275-6. doi: 10.1038/s41571018-0155-3

Conflict of Interest: The authors declare that the research was conducted in the absence of any commercial or financial relationships that could be construed as a potential conflict of interest.

Copyright $\odot 2020$ Franke, Pillai, Hoogenboezem, Gijbels, Matlung, Geissler, Olsman, Pottgens, van Gorp, Ozsvar-Kozma, Saito, Matozaki, Kuijpers, Hendriks, Kraal, Binder, de Winther and van den Berg. This is an open-access article distributed under the terms of the Creative Commons Attribution License (CC BY). The use, distribution or reproduction in other forums is permitted, provided the original author $(s)$ and the copyright owner(s) are credited and that the original publication in this journal is cited, in accordance with accepted academic practice. No use, distribution or reproduction is permitted which does not comply with these terms. 